liberated in the process of condensation, which will tend to set up convection currents.

Prof. J. von Hann's opinion on the subject, in the latest edition of his "Handbuch der Klimatologie" is that the question cannot be definitely answered at present, but that the effect, if any, should be greater in the tropics than in higher latitudes. Dr. G. T. Walker, of the Meteorological Office, Simla, is of a similar opinion. He states that if forests have any influence at all on the rainfall, it is probably not greater in India than 5 per cent.

R. C.

\section{OERSTED AND THE ELECTRIC THEORY} OF LIGHT.

I N Sir John W. F. Herschel's classical article on light (dated 1827 ) in the "Encyclopædia Metropolitana" of 1830 , p. 439, there is a vague reference to a theory of light then recently propounded by Oersted, in which he sought to explain the nature of light-waves as a succession of minute electric sparks. Desiring to follow up this reference, the writer of this notice consulted, but fruitlessly, all the writings of Oersted within his reach. Thereupon he applied for information to Prof. Absalon Larsen, of Copenhagen, who, after consultation with Prof. Christiansen, kindly directed the writer to sources not available in London, and furnished the extracts now given from Oersted's writings.

The theory of light suggested by Oersted was first advanced in a remarkable book, written in the German language, and published in Berlin in 1812 , under the title, "Ansicht der chemischen Naturgesetze," von H. C. Oersted. The theory of light occupies only a small part of this book (298 pages in all), which is of a much wider scope. Oersted proposes to refer all chemical phenomena to fundamental agents (forces), hoping thus to initiate a development of theoretical chemistry analogous to the development which the introduction of simple laws had brought about in mechanics. A quotation from his own introduction, pages $7-9$, will state the position:-

It will not be without use here at the outset to review the whole road to be travelled. We intend to make the beginning of our investigation with a demonstration and arrangement of all bodies according to their chemical nature. Then we will set forth some considerations about the ordinary chemical actions known to us, and will show from them that all chemical changes hitherto investigated can be referred to two widely extended forces of Nature. We will at the same time demonstrate that these forces are able to act not only by direct, but also by indirect, contact; that consequently they can be conducted. This will lead us to those chemical circuitactions which have already been known to us for a long time in Galvanism. And, lastly, this will bring us on to demonstrate chemical forces in their free activity, and so at the same time to make evident their identity with electrical forces. Here, then, we shall reverse the course of our investigation, and directing our attention to electrical forces, we shall seek to discover how these also can be related to the chemical form of action. And besides we then become aware that the electric forces, like the chemical ones, are two, and that they at the same time are opposed; that both are of general application, and that, from the state of relative rest in which they exist in bodies, they can pass over into activity when aroused by external forces. ... After we have in this way set forth the broad connection of chemical and electrical actions, in these two opposite directions, we shall, relying on an investigation into the nature of conduction, try to show under what conditions the two forces produce Heat, and under what conditions they produce Light. We shall thereby regard these great phenomena in a far more intimate connection with the rest of nature than werc possible according to the ordinary view.

Starting from the nature of electric conduction, Oersted then attempts to show the conditions under which the two opposing agencies produce heat and light respectively. His ideas about conduction he develops on pages 138 , I 39 :-

If, therefore, one of the electric forces is propagated through space, this occurs in the following way: that it attracts the opposing force in the nearest zone, binds it, and itself in turn suffers a diminution from it, in consequence of which the next zone receives actually the overplus of the same force as it spreads, but itself excites a new zone of the opposing force, so as again to react, and so forth. One may express all this by saying that Electricity is propagated by wave-motion (die Electricität verbreitet sich undulatorisch).

As to the conditions under which the conduction of electricity produces heat, Oersted writes on pp. $164-165:-$

We have seen that Conduction consists in a disturbance running through all points of the body and in a restitution of equilibrium. So long as the Conduction is complete, the restitution will always be brought about by the mutual attraction of the force evoked out of equilibrium. But when by reason of a forced conduction a greater quantity of force penetrates the body than the latter is able spontaneously to conduct away, then at once the interiorly-disturbed equilibrium cannot be restored again by the body's own forces... This condition, in which equilibrium is disturbed at every point of the body, but in such wise that no recognisable separation of the forces is attained, gives us the phenomenon of Heat. ...

To distinguish it from other theories of heat, the mechanical, which regards heat as a vibration of material particles, and the chemical, which assumes a particular substance (caloric), Oersted calls his own the dynamical theory.

As regards light, Oersted first shows that heat may be transformed into light, and vice versâ, and he therefore considers heat and light as produced by the same two agencies. The difference is that, as stated above, for the production of heat no real separation of the two agencies is needed, whereas for the production of light the tension of the opposite forces or agencies must reach its maximum value and produce a discharge. The following passages are from p. 222 :-

so we must content ourselves with knowing that Light will be produced if the tension of opposition of the internal forces has attained its maximum and passes over into equalisation. 
He then continues:-

The propagation of Light occurs, as we have already seen, by dynamical undulations, for so we call the uninterrupted alternation of the opposing forces. This view stands between the Undulatory theory which Huygens and Euler taught and the Emanation theory of the Newtonian school, almost in the same way as the dynamical theory of Heat between the mechanical and electrical theories. Schelling, in his Weltseele, has recognised the possibility of such a view.

Besides these extracts from the "Ansicht der chemischen Naturgesetze," Oersted expounded his theory of light in a particular communication which he made to the Royal Danish Society of Science, and of which an abstract is printed in its Proceedings for the year $1815-16$, pp. 12-15. One sentence will suffice as a summary of this abstract:-

According to the theory which has been set forth here, one may fairly well consider a ray of Light as a succession of immensely small electric sparks which might be called the elements of Light.

It is evident that, with all his ingenious insight, Oersted was far from having formulated an electric theory of light in terms which would admit of verification. His perception that electric forces were called into play in the displacements of the luminiferous waves was obscured by the view which he held of conduction; for, surely, the condition of the quasi-elastic actions called forth in the propagation of light should have been that the forces or agencies at work must not attain so great a value as to produce a discharge, as we now understand it. Indeed, in the existing state of knowledge, when as yet the quasielasticity of dielectrics was unknown, the foundation facts for an electric theory were not available. The remarkable fact is that in the paucity of available facts his speculations took him so far as they did along the road of progress.

Silvanus P. Thompson.

\section{SCIENCE AND RESERVATIONS. ${ }^{1}$}

W

$\mathrm{HEN}$ a district interesting to geologist and naturalist alike is handed over to a body of scientific investigators, the result in these days of intensive research is likely to be important. Dr. Conwentz, the indefatigable pioneer of natureprotection, has edited a volume of 700 pages, which gives the results of such a study in the case of the Plagefenn at Chorin, in Prussia, a district of marshes, lakes, islands, and wooded country. Of course, there are gaps in the mass of knowledge accumulated during several years, in the fauna and lower flora, for instance. But the whole work is a remarkable study in classification and generalisation.

The relations of water and earth, for which the historical records of the district are very useful, have seldom been studied so minutely, especially in

1 " Beitrïge zur Naturdenkmalpflege." Herausgegeben von $\mathbf{H}$. Conwentz. Dritter Band-"Das Plagefenn bei Chrin." Ergebnisse der Durchforschung eines Naturschutzgebietes der preussischen Forstverwaltung By H. Conwentz, F. Dahl, R. Kolkwitz, H. Schroeder, J. Stoller and E. Ulrich. Pp. xvit688. (Berlin: Gebrüder Borntraeger, rox). Price 18.75 marks

NO. 2235, VOL. 89] reference to the lower vegetation. Dr. $H$. Schroeder describes the diluvial, and Dr. J. Stoller the alluvial, structure. On their foundations, Dr. E. Ulrich bases his botanical study. This, and the monograph on the fauna, are fine studies. As contributions to ecology they are of great value. Many readers should be able to obtain a better idea of the intricacies of plant communities from such a monograph as Dr. Ulich's than from a general work on the subject. The sociology of plants and animals, as conditioned and initiated by geological and meteorological forces, has still alì the fascination of a young science. Excellent diagrams and maps illustrate the social processes, so well marked in this district, which Dr. U1rich praises as a model of biological complexity and natural beauty. Professor Kolkwitz's essay on the plankton is placed at the end of the volume, but should be read with Dr. Ulrich's contribution.

The account of the fauna could not have been in better hands than in those of Prof. F. Dahl. His general introduction on methods of research and his conclusions on the relations between animal and plant communities are fresh and important.

The analytical lists are carefully executed; that of the fauna extends to more than 200 pages. The index is a good one.

The keynote of the whole study, and the point of departure and of arrival alike, is the coast-line of a fresh-water lake; and there are few more interesting sites for the study of organic life. Our own country, it may be observed, has an abundance of similar districts, more or less useless to the agriculturist, but of enormous value for scientific research.

A. E. Crawiey.

\section{NOTES.}

ARRANGEMENTS have been made for the inclusion of two organised discussions in the proceedings of Section H (Anthropology) during the forthcoming meeting of the British Association at Dundee. On Friday, September 6, a discussion on the ethnological aspects of Scottish folklore will be opened by Mr. W. Crooke, president of the Folklore Society, and papers will be contributed by Mr. E. S. Hartland, Mr. W. J. Brodie-Innes, and Canon J. A. McCulloch. On Monday, September 9, the president of the section, Prof. G. Elliot Smith, F.R.S., will read a paper on the distribution of megalithic monuments, in which he will develop the theories as to the racial affinities of their builders which he has recently put forward. In the discussion which will follow, Prof. Ridgeway, Prof. J. L. Myres, Prof. W. Boyd Dawkins, Dr. T. Ashby, and others have promised to speali.

The summary of the weather issued by the Meteorological Office for the week ending August 24 shows that the general conditions were again extremely unsettled over the United Kingdom as a whole, but in some localities in Scotland, Ireland, and the north-east of England rain is said to have been less common than elsewhere. The deficiency of temperature exceeded $3^{\circ}$ in most districts, and the south-west of England was the only district where the highest day 